\title{
Influence of tidal-range change and sediment compaction on Holocene relative sea-level change in New Jersey, USA
}

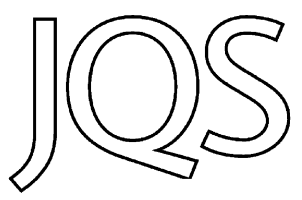

BENJAMIN P. HORTON, ${ }^{1,2 *}$ SIMON E. ENGELHART, ${ }^{1,3}$ DAVID F. HILL, ${ }^{4}$ ANDREW C. KEMP, ${ }^{1,5}$ DARIA NIKITINA, ${ }^{6}$ KENNETH G. MILLER $^{7}$ and W. RICHARD PELTIER ${ }^{8}$

${ }^{1}$ Sea Level Research, Department of Earth and Environmental Science, University of Pennsylvania, Philadelphia, Pennsylvania, USA

${ }^{2}$ Institute of Marine and Coastal Sciences, Rutgers University, New Brunswick, USA

${ }^{3}$ Department of Geosciences, University of Rhode Island, Kingston, Rhode Island, USA

${ }^{4}$ School of Civil and Construction Engineering, Oregon State University, Corvallis, Oregon, USA

${ }^{5}$ School of Forestry and Environmental Studies, Yale University, New Haven, Connecticut, USA

${ }^{6}$ Department of Geology and Astronomy, West Chester University, West Chester, Pennsylvania, USA

${ }^{7}$ Department of Earth and Planetary Sciences, Rutgers University, Piscataway, New Jersey, USA

${ }^{8}$ Department of Physics, University of Toronto, Toronto, Ontario, Canada

Received 10 October 2012; Revised 24 February 2013; Accepted 25 February 2013

\begin{abstract}
We investigated the effect of tidal-range change and sediment compaction on reconstructions of Holocene relative sea level (RSL) in New Jersey, USA. We updated a published sea-level database to generate 50 sea-level index points and ten limiting dates that define continuously rising RSL in New Jersey during the Holocene. There is scatter among the index points, particularly those older than $7 \mathrm{ka}$. A numerical model estimated that paleotidal range was relatively constant during the mid and late Holocene, but rapidly increased between 9 and $8 \mathrm{ka}$, leading to an underestimation of RSL by $\sim 0.5 \mathrm{~m}$. We adjusted the sea-level index points using the paleotidal model prior to assessing the influence of compaction on organic samples with clastic deposits above and below (an intercalated sea-level index point). We found a significant relationship $(p=0.01)$ with the thickness of the overburden $(r=0.85)$. We altered the altitude of intercalated index points using this simple stratigraphic relationship, which reduced vertical scatter in sea-level reconstructions. We conclude that RSL rose at an average rate of $4 \mathrm{~mm} \mathrm{a}^{-1}$ from $10 \mathrm{ka}$ to $6 \mathrm{ka}, 2 \mathrm{~mm} \mathrm{a}^{-1}$ from $6 \mathrm{ka}$ to $2 \mathrm{ka}$, and $1.3 \mathrm{~mm} \mathrm{a}^{-1}$ from $2 \mathrm{ka}$ to AD 1900.
\end{abstract}

Copyright (C) 2013 John Wiley \& Sons, Ltd.

KEYWORDS: sea level; Holocene; sediment compaction; tidal range; index points.

\section{Introduction}

Holocene relative sea level (RSL) on the US Atlantic coast is the product of eustatic, isostatic, tectonic and local contributions. The eustatic function includes the transfer of mass between the ocean and ice sheets, ocean water density (steric) changes from temperature and salinity variations, and gravitational and rotational changes (geoid contribution). Isostasy is the total effect of glacio- and hydro-isostasy. Tectonic contributions are assumed to be localized or negligible for the Holocene (Sykes et al., 2008). Local processes include tidal-range change and sediment compaction.

Sea-level index points are individual reconstructions of sea level with quantified age and vertical uncertainties. Groups of sea-level index points describe trends and patterns in RSL change through time and space. Compiled index points from New Jersey show continuous RSL rise during the Holocene (e.g. Daddario, 1961; Stuiver and Daddario, 1963; Bloom, 1967; Meyerson, 1972; Psuty, 1986; Miller et al., 2009; Engelhart and Horton, 2012). During deglaciation the contribution of global ice melt to sea-level change averaged $10 \mathrm{~mm} \mathrm{a}^{-1}$, although peak rates exceeded $47 \mathrm{~mm} \mathrm{a}^{-1}$ during meltwater pulse 1a at 14.5 ka (e.g. Deschamps et al., 2012). Empirical data and glacial isostatic adjustment (GIA) models suggest a significant reduction in the eustatic contribution at approximately $7 \mathrm{ka}$; since when ocean volume changed only by a few meters (Peltier, 1998; Lambeck and Chappell, 2001; Mitrovica and Milne, 2002; Bassett et al., 2005). GIA models

${ }^{*}$ Correspondence: B. P. Horton, ${ }^{2}$ Institute of Marine and Coastal Sciences, as above.

Email: bphorton@marine.rutgers.edu predict that New Jersey is influenced by ongoing subsidence in response to collapse and retreat of the Laurentide Ice Sheet forebulge and the return flow of mantle material towards formerly glaciated areas (Tushingham and Peltier, 1992). The models (e.g. Peltier, 2004; Engelhart et al., 2011) and RSL reconstructions (Psuty, 1986; Miller et al., 2009; Engelhart et al., 2009; Engelhart and Horton, 2012) suggest that the eustatic and isostatic contributions did not vary spatially within New Jersey. RSL predictions from GIA models predictions are similar for sites in northern and southern New Jersey (Fig. 1c) because they are a similar distance to the center of the former Laurentide Ice Sheet in Hudson Bay (Peltier, 2004) and consequently shared the same eustatic and isostatic history. This spatial uniformity is also seen in Holocene sea-level reconstructions, where sea-level index points from Cheesequake in northern New Jersey (Psuty, 1986; ; Fig. 1a) are in broad agreement with contemporaneous ones from sites in central and southern New Jersey (Englehart and Horton, 2012). Therefore, the relatively small differences among sites and sea-level index points of the same age are assumed to be a product of local processes.

The contribution of local factors to reconstructed Holocene RSL change in New Jersey is unknown. We analyzed a database of sea-level index points (Engelhart and Horton, 2012) to estimate the influence of tidal-range change and compaction (local processes) on RSL reconstructions from New Jersey. If tidal range changed through time, RSL reconstructions based upon tide-level indicators will differ from the actual sea level (Gehrels et al., 1995; Shennan et al., 2000b; Shennan and Horton, 2002; Hall et al., 2013). We use a numerical paleotidal model (Hill et al., 2011) that 
predicts temporal variations in tidal range to modify the vertical uncertainty of individual index points. Compaction reduces sediment volume by rearrangement of the mineral matrix and biodegradation (Kaye and Barghoorn, 1964; Allen, 2000; Brain et al., 2011). This process lowers the altitude of the land surface (Cahoon et al., 2002), causing samples used for RSL reconstruction to have a lower elevation compared to where they formed (e.g. Brain et al., 2012). We suggest that there was a significant change in tidal range in the early Holocene and demonstrate that compaction was a considerable driver of RSL change in New Jersey with deviations of up to $10 \mathrm{~m}$ from the regional RSL record. The application of a first-order method of decompaction based on the stratigraphic position of index points reduces vertical scatter in the reconstructions.

\section{Sea-level index points}

Sea-level index points are estimates of the position of RSL in space and time. Engelhart and Horton (2012) produced a standardized database of Holocene sea-level index points from published literature for the US Atlantic coast. Salt marshes provided all sea-level index points (basal and intercalated) in the New Jersey database. Individual index points are presented as boxes that incorporate estimated age and vertical uncertainty. Each index point possessed the following:

1. Location: consisting of its geographical coordinates.

2. Radiocarbon age (and uncertainty): calibrated using CALIB 6.1 (Reimer et al., 2009) with a $2 \sigma$ error, where zero is AD 1950. In this paper, we expressed the unit for thousands of years as ' $k a$ ', both for ages and time spans.

3. Elevation (and uncertainty): RSL was reconstructed using sea-level indicators and their indicative meaning that was defined from analogous modern examples. The indicative meaning describes the relationship of a sea-level indicator to elevation in the tidal frame and is comprised of a midpoint that is a tidal datum (the reference water level) and a vertical range (the indicative range). This approach allows samples of varied origins to be plotted together as a single RSL curve. We estimated three indicative meanings for salt marsh samples (Table 1) from the zonation of vegetation and assemblages of microfossils, and $\delta^{13} \mathrm{C}$ values of bulk sediment (Kemp et al., 2012a, 2012b). RSL is calculated by subtracting the reference water level from sample altitude. Engelhart and Horton (2012) calculated a vertical error for each index point from the indicative range and factors inherent in the collection and processing of samples for sea-level research (e.g. surveying, angle of borehole, sample thickness).

\section{Tidal-range change}

If tidal range was greater in the past, the reference water-level value would be greater and consequently RSL would be lower. Therefore, failing to account for tidal-range increase would lead to an underestimation of the true magnitude of RSL change. Paleotidal data for New Jersey were predicted using a nested modeling approach. Complete details are available in Hill et al. (2011) and Hall et al. (2013), and only a brief overview is presented here. A global tidal model (Griffiths and Peltier, 2008, 2009), including self-attraction and loading, drag in shallow seas and internal tide drag, was first used to compute tidal constituent amplitudes and phases on an $800 \times 800$ regular grid. At this resolution, the grid spacing varies smoothly from about $50 \mathrm{~km}$ in the Tropics to about $5 \mathrm{~km}$ around the coast of Greenland. The results from the global model forced the open boundary of a regional tidal model spanning the western Atlantic Ocean, the Gulf of Mexico and the Caribbean Sea. The regional model (ADCIRC; Luettich and Westerink, 1991) used an unstructured finiteelement computational mesh that allows for variable spatial resolution. The mesh for the present study had roughly 500000 elements with nearshore resolution of $1-2 \mathrm{~km}$. This resolution was sufficient to retain many coastal embayments and estuaries, though other very small features were filtered out. To validate its use, data were computed at approximately 250 NOAA tide-gauge locations on the US Atlantic and Gulf coasts (from Maine to Texas). Hill et al. (2011) showed a very

Table 1. Summary of the indicative meanings used to generate the basal and intercalated sea-level index points of the New Jersey database.

\begin{tabular}{|c|c|c|c|}
\hline Sample type & Evidence & $\begin{array}{l}\text { Reference } \\
\text { water level }\end{array}$ & Indicative range \\
\hline High marsh environment & $\begin{array}{l}\text { High marsh plant macrofossils (e.g. Kemp et al., 2012a). } \\
\text { Foraminiferal (e.g. Kemp et al., 2012b) assemblages dominated } \\
\text { by high marsh taxa }\end{array}$ & $(\mathrm{HAT}-\mathrm{MHW}) / 2$ & HAT-MHW \\
\hline Low marsh environment & $\begin{array}{l}\text { Low marsh plant macrofossils (e.g. Kemp et al., 2012a). } \\
\text { Foraminiferal assemblages dominated by low marsh taxa } \\
\text { (e.g. Kemp et al., 2012b) }\end{array}$ & $(\mathrm{MHW}-\mathrm{MTL}) / 2$ & MHW-MTL \\
\hline $\begin{array}{l}\text { Undifferentiated salt marsh } \\
\text { environment }\end{array}$ & $\begin{array}{l}\text { Author listing of unnamed salt marsh plant macrofossils or identification } \\
\text { only to genus level (e.g. Donnelly et al., 2001, 2004). } \\
\text { Foraminiferal assemblages dominated by high and low marsh taxa } \\
\text { (e.g. Kemp et al., 2012b). } \\
\text { Diatom assemblage dominated by brackish and or marine taxa } \\
\text { (e.g. Cinquemani et al., 1982) }\end{array}$ & $(\mathrm{HAT}-\mathrm{MTL}) / 2$ & HAT-MTL \\
\hline Marine limiting & $\begin{array}{l}\text { Identifiable in situ marine shells (e.g. Psuty et al., 1986) or calcareous } \\
\text { foraminiferal assemblages (e.g. Miller et al., 2009) in clastic sediment }\end{array}$ & MTL & Below MTL \\
\hline Terrestrial limiting & $\begin{array}{l}\text { Peat that does not meet the above requirements to be classified as an index } \\
\text { point (e.g. Psuty et al., 1986) }\end{array}$ & MTL & Above MTL \\
\hline
\end{tabular}

MHW, mean high water; MTL, mean tide level; HAT, highest astronomical tide. 
good agreement between the NOAA tide-gauge observations and independent model predictions. The correlation coefficient $(r)$ between the two sets of mean higher high water values was 0.93 .

For paleobathymetries, depth changes from the ICE-5G GIA model of Peltier (2004) were interpolated on to the regional grid. Tidal amplitudes and phases (obtained from harmonic analysis of the regional model results) were converted to tidal data using the harmonic constant datum method of Mofjeld et al. (2004). The paleotidal models do not include the effects of sediment infilling of estuaries and coastal lowlands or freshwater discharge from the catchments (Shennan et al., 2000b).

The reference water level and indicative range for all index points were corrected for the local tidal conditions that prevailed at the time of sample deposition using hindcasts from the paleotidal model. Computational runs were carried out at $1 \mathrm{ka}$ intervals from 10 ka to present day. Following Hill et al. (2011), the percentage change in each tidal datum between present day and the model runs was used to provide the absolute values. Data at locations other than the model grid points (i.e. sites with index points; Fig. 1a) were obtained through interpolation. However, some nodes that were in close proximity to the coastline at a given time interval would alternate between wet and dry during the tidal cycle. This intermittent submergence adversely affected the harmonic analysis at these locations. To address this, data at these nodes were first replaced with mean values from neighboring nodes. Then, a surface-fitting algorithm computed data on a high-resolution rectangular grid, based on the scattered data from the finite-element mesh. This grid was allowed to extend shoreward of the coastline at any given time slice, in order to extrapolate results to locations of interest.

\section{Sediment compaction}

Sea-level index points may have undergone post-depositional displacement in altitude due to compaction of underlying sediment. This is a one directional process that can only lower altitude in comparison to where the sample was originally deposited, resulting in an RSL reconstruction that is too low. Subdivision of index points into basal and intercalated categories provides an initial assessment of the influence of compaction (Shennan and Horton, 2002; Horton and Shennan, 2009). Intercalated samples are derived from easily compressible organic sediment with clastic units above and below in the sedimentary column (Shennan and Horton, 2002). Basal samples are from an organic sedimentary unit that directly overlays a relatively incompressible substrate (Jelgersma, 1961). Therefore, the influence of sediment compaction for basal samples is minor compared to index points from peat intercalated between thick Holocene clastic sediments (Jelgersma, 1961; Kaye and Barghoorn, 1964). Compaction of intercalated index points can be estimated from three stratigraphical parameters commonly reported in, or estimated from, the original publication: (i) thickness of sediment overburden; (ii) depth to incompressible substrate; and (iii) thickness of the whole sedimentary sequence. We do not account for variation in sediment types, including the proportion of different grain size distributions, organic content, water content or drainage histories, because this information is fragmentary in the original literature for both reporting and methodology.

Compaction of intercalated samples was estimated by modifying RSL predictions (Engelhart et al., 2011) from the ICE-6G VM5b model to fit the basal index points after adjustment for paleotidal changes. It was necessary to use a
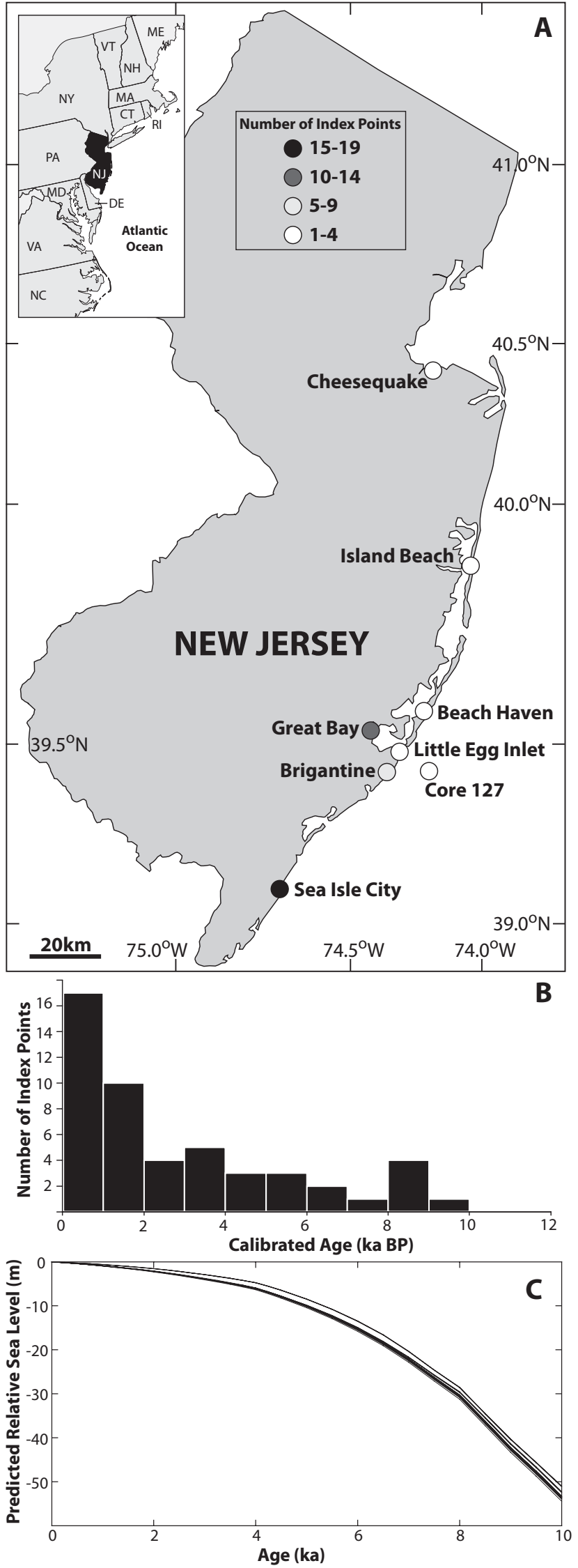

Figure 1. (A) Location of sites where sea-level index points were generated. (B) Temporal distribution of sea-level index points from New Jersey. (C) Holocene sea-level predictions of the ICE-6G VM5b (Engelhart et al., 2011) for each of the study sites of New Jersey where sea-level index points were generated. 
curve to ensure that all intercalated index points had a contemporary estimate of compaction-free RSL. The vertical difference between each intercalated index point (at its center without consideration of age or vertical uncertainty) and the fitted RSL curve is attributed entirely to sediment compaction. Correlation coefficients were used to compare this residual to the three readily available stratigraphic parameters to test for statistical significance (Shennan et al., 2000a; Horton and Shennan, 2009). Following Edwards (2006), we used the linear regression between the residual and the significant stratigraphic parameters to 'decompact' the intercalated index points. Decompaction will elevate the altitude of index points and move the lower points into closer agreement with the modeled curve (Edwards, 2006).

\section{Regional sea level, tidal-range change and sediment compaction in New Jersey}

The updated New Jersey database includes seven new index points not previously reported (Table 2). There are 50 sealevel index points (Fig. 1a) and ten data points that provide limits on the maximum and minimum elevation of RSL. In contrast to other regions of the US Atlantic coast (Engelhart and Horton, 2012), the temporal distribution of sea-level index points is relatively even, with $>25 \%$ being of early to mid Holocene age (Fig. 1b). Spatially, however, there are no index points between $39.8^{\circ} \mathrm{N}$ and $40.4^{\circ} \mathrm{N}$ latitude and only four index points (\#10, 11, 12 and 36) from northern New Jersey (Cheesequake Marsh; Psuty, 1986). These northern index points are not distinguishable from those situated in central and southern New Jersey, demonstrating that they can be meaningfully combined into a single RSL region (Fig. 4).

\section{Influence of paleotidal-range change}

RSL changes affect shelf width and bathymetric depths, and consequently change the reflection and amplification of tidal waves and the distribution of frictional dissipation of the tidal energy that is transferred from the deep oceans to the shallow shelf regions (e.g. Hinton, 1992; Shennan et al., 2000b; Uehara et al., 2006; Hill et al., 2011). Today, the Great Diurnal Range (GT) in New Jersey is microtidal $(<2 \mathrm{~m})$, with offshore regions $<0.8 \mathrm{~m}$. GT is the difference between mean higher high water and mean lower low water (NOAA, 2000).

Paleotidal modeling indicates that GT tripled between $9 \mathrm{ka}$ and $8 \mathrm{ka}$ at the basin-wide scale (Fig. 2). Uehara et al. (2006) and Hill et al. (2011) attributed it to a combination of the quasi-resonant condition of the Atlantic basin with respect to the semi-diurnal frequency, the opening the Hudson Strait in the early Holocene and the changing extent of the continental shelf. In the mid Holocene tides were amplified south of Long Island (northern New Jersey), likely because of shelf resonance. Based upon present-day bathymetry, the shelf width southeast of Long Island is shorter than a quarter tidal wavelength ( 150 vs. $250 \mathrm{~km})$. At $5 \mathrm{ka}$ (Hill et al., 2011), shelf depths in that region were approximately $25 \mathrm{~m}$ less, reducing the quarter wavelength of the semi-diurnal tide by $\sim 75 \mathrm{~km}$, bringing it into much closer proximity to the shelf width, and enhancing resonance. GT in the lower Delaware Bay remained fairly constant through time, but ranges in the upper bay doubled from ca. 4 ka to present because the Bay evolved steadily from a narrow river to a funnel-shaped bay. Funnel-shaped estuaries amplify tides with up-bay distance, primarily due to nonlinear overtides (e.g. Parker, 1991).

Changes in tidal range would not affect all types of sealevel index points (high marsh, low marsh, undifferentiated marsh) evenly (Fig. 3a, b). The reference water level of a hypothetical high-marsh deposit from Brigantine, NJ, at 9 ka would be $1 \mathrm{~m}$ higher relative to the present day, and thus RSL $1 \mathrm{~m}$ lower. The increase in the indicative range is minor $( \pm$ $0.04 \mathrm{~m}$ ), because the relationship between highest astronomical tide and mean high water remains near constant through time. The reference water-level increase for Brigantine at $9 \mathrm{ka}$ is reduced $(0.5 \mathrm{~m})$ but with larger error terms $( \pm 0.5 \mathrm{~m})$ for hypothetical low marsh or undifferentiated salt marsh samples. The reference water level of a hypothetical high-marsh deposit from Brigantine (Fig. 1a) at 9 ka would be $1 \mathrm{~m}$ higher than a modern high-marsh deposit, and thus reconstructed RSL would be $1 \mathrm{~m}$ lower. The increase in the indicative range is minor $( \pm 0.04 \mathrm{~m})$, because the relationship between highest astronomical tide and mean high water remains near constant through time. The reference water-level increase for Brigantine at $9 \mathrm{ka}$ is less $(0.5 \mathrm{~m})$ for hypothetical low marsh or undifferentiated salt marsh samples, but with larger changes in the absolute indicative range $( \pm 0.5 \mathrm{~m})$. Despite the changes in paleotides (particularly between 9 and $8 \mathrm{ka}$ ) the absolute change for a salt marsh sea-level indicator from New Jersey is relatively small due to the modern micro-tidal regime. The maximum decrease in $\mathrm{RSL}(0.52 \mathrm{~m}$; index point \#40) and increase in error $( \pm 0.31 \mathrm{~m}$; index points \#13 and 14) in the database is small compared to the $>20 \mathrm{~m}$ of RSL rise observed during the Holocene in New Jersey (Fig. 3c).

\section{Influence of sediment compaction}

The effects of compaction on RSL reconstructions over millennial timescales have been assessed through regional (e.g. Shennan et al., 2000a; Edwards, 2006; Törnqvist et al., 2008; Horton and Shennan, 2009) and local (e.g. Gehrels, 1999; Long et al., 2006) datasets. In New Jersey, intercalated index points record comparable or lower RSL than the curve fitted to basal index points (Fig. 4a). An intercalated index point (\#40) at 8.5 ka suggests RSL (after paleotidal correction) was $-30.7 \pm 1.8 \mathrm{~m}$, which is more than $10 \mathrm{~m}$ lower than basal index points of similar age. The intercalated index point was from Little Egg Inlet and identified as a salt marsh peat by microfossil and palynological analysis (Field et al., 1979). In the Late Holocene there are six intercalated index points with $1-4 \mathrm{~m}$ differences in RSL compared to basal index points, with the oldest (\#39) plotting below a marine limiting date (Miller et al., 2009). In eastern England, Horton and Shennan (2009) showed differences of up to $6 \mathrm{~m}$ between basal and intercalated index points of similar age at individual sites. Similarly, Long et al. (2006) identified 2-3 m RSL differences between late Holocene basal and intercalated index points deposited in southern England. In the Mississippi Delta, USA, Törnqvist et al. (2008) observed $>2 \mathrm{~m}$ variation in elevation of an isochronous $1.4 \mathrm{ka}$ peat that was overlain with clastic material of variable thickness.

Comparison of the residuals between intercalated index points and the RSL curve fitted to basal data demonstrates that there is a strong $(r=0.64)$ and significant (at the $1 \%$ level) relationship between the overburden of the sample and the magnitude of the residual (Fig. 4b). The intercalated index point from Little Egg Inlet again plots as outlier. Little Egg Inlet was dredged during the 20th century and is also a location of significant sand mining by New Jersey Department of Environmental Protection (Byrnes et al., 2004). Both processes remove sediment overburden and likely make the measured thickness of overlying sediment an underestimate. Removing this index point from the analyses improves the relationship between the thickness of the overburden and 
Table 2. Summary of sea-level index points and limiting data from the New Jersey database.

\begin{tabular}{|c|c|c|c|c|c|c|c|c|c|c|c|}
\hline $\begin{array}{l}\text { Index } \\
\text { points }\end{array}$ & Location & Longitude & Latitude & Labcode & ${ }^{14} \mathrm{C}$ age $\pm 1 \sigma$ & $\begin{array}{l}\text { Calibrated } \\
\text { age range }\end{array}$ & $\begin{array}{l}\text { Tidal range } \\
\text { correctn }(\mathrm{m})\end{array}$ & $\begin{array}{c}\text { Compctn } \\
\text { correctn } \\
(\mathrm{m})\end{array}$ & RSL (m) & Citation & Code \\
\hline \multicolumn{12}{|c|}{ Index points (Basal) } \\
\hline 1 & Beach Haven Inlet & -74.250 & 39.470 & $848-26$ & $7790 \pm 130$ & $8987-8387$ & -0.38 & & $-20.55 \pm 1.70$ & Strahl et al. (1974) & 3 \\
\hline 2 & Beach Haven Inlet & -74.250 & 39.470 & $833-25$ & $7860 \pm 190$ & 9256-8334 & -0.38 & & $-20.55 \pm 1.70$ & Strahl et al. (1974) & 3 \\
\hline 3 & Beach Haven Inlet & -74.250 & 39.470 & $816-35$ & $8210 \pm 120$ & $9481-8779$ & -0.38 & & $-21.55 \pm 1.70$ & Strahl et al. (1974) & 3 \\
\hline 4 & Brigantine Marsh & -74.390 & 39.426 & Y-1284 & $5890 \pm 100$ & $6951-6453$ & -0.07 & & $-13.02 \pm 0.82$ & Stuiver and Daddario (1963) & 3 \\
\hline 6 & Brigantine Marsh & -74.426 & 39.485 & Y-1331 & $1890 \pm 40$ & $1922-1720$ & -0.02 & & $-2.56 \pm 0.77$ & Stuiver and Daddario (1963) & 3 \\
\hline 7 & Brigantine Marsh & -74.424 & 39.483 & Y-1281 & $3000 \pm 90$ & $3387-2929$ & 0.02 & & $-4.63 \pm 0.75$ & Stuiver and Daddario (1963) & 3 \\
\hline 8 & Brigantine Marsh & -74.419 & 39.479 & Y-1282 & $3830 \pm 100$ & $4517-3929$ & -0.03 & & $-7.38 \pm 0.79$ & Stuiver and Daddario (1963) & 3 \\
\hline 9 & Brigantine Marsh & -74.405 & 39.454 & Y-1283 & $4760 \pm 80$ & $5642-5315$ & -0.08 & & $-10.32 \pm 0.83$ & Stuiver and Daddario (1963) & 3 \\
\hline 10 & Cheesequake Marsh & -74.300 & 40.400 & QC-844 & $1210 \pm 185$ & $1509-738$ & -0.01 & & $-2.63 \pm 0.85$ & Cinquemani et al. (1982) & 3 \\
\hline 11 & Cheesequake Marsh & -74.300 & 40.400 & QC-847 & $1960 \pm 130$ & 2305-1572 & 0.05 & & $-2.79 \pm 0.81$ & Cinquemani et al. (1982) & 3 \\
\hline 12 & Cheesequake Marsh & -74.300 & 40.400 & QC-842 & $2080 \pm 160$ & $2457-1625$ & 0.05 & & $-3.26 \pm 0.80$ & Cinquemani et al. (1982) & 3 \\
\hline 13 & Core 127 & -74.256 & 39.416 & Unknown & $7130 \pm 100$ & $8170-7749$ & -0.33 & & $-17.94 \pm 0.91$ & Miller et al. (2009) & 3 \\
\hline 16 & Edwin B. Forsythe & -74.418 & 39.495 & OS-66518 & $950 \pm 30$ & 926-794 & 0.00 & & $-2.09 \pm 0.28$ & This publication & 1 \\
\hline 17 & Edwin B. Forsythe & -74.418 & 39.495 & OS-70444 & $1188 \pm 30$ & $1228-1004$ & 0.00 & & $-2.23 \pm 0.28$ & This publication & 1 \\
\hline 18 & Edwin B. Forsythe & -74.418 & 39.495 & OS-70442 & $1249 \pm 13$ & $1263-1147$ & 0.00 & & $-2.43 \pm 0.28$ & This publication & 1 \\
\hline 19 & Edwin B. Forsythe & -74.418 & 39.495 & OS-70443 & $1502 \pm 14$ & $1407-1349$ & 0.00 & & $-2.70 \pm 0.28$ & Kemp et al. (2012a) & 1 \\
\hline 20 & Edwin B. Forsythe & -74.418 & 39.495 & OS-70445 & $1541 \pm 14$ & $1517-1379$ & 0.00 & & $-2.93 \pm 0.28$ & Kemp et al. (2012a) & 1 \\
\hline 21 & Edwin B. Forsythe & -74.418 & 39.495 & OS-66514 & $1550 \pm 25$ & $1521-1383$ & 0.00 & & $-3.07 \pm 0.28$ & Kemp et al. (2012a) & 1 \\
\hline 22 & Great Bay & -74.349 & 39.561 & Unknown & $3035 \pm 120$ & $3474-2879$ & 0.00 & & $-4.04 \pm 0.76$ & Psuty et al. (1986) & 3 \\
\hline 23 & Great Bay & -74.324 & 39.522 & Unknown & $4175 \pm 145$ & 5264-4256 & -0.09 & & $-8.44 \pm 0.84$ & Psuty et al. (1986) & 3 \\
\hline 24 & Great Bay & -74.324 & 39.522 & Unknown & $4495 \pm 125$ & $5565-4843$ & -0.09 & & $-8.44 \pm 0.84$ & Psuty et al. (1986) & 3 \\
\hline 25 & Island Beach & -74.094 & 39.803 & GX-19017 & $5625 \pm 200$ & $6883-5947$ & -0.20 & & $-10.57 \pm 0.84$ & Miller et al. (2009) & 3 \\
\hline 26 & Sea Island City & -74.700 & 39.200 & QC-850 & $920 \pm 160$ & $1176-559$ & 0.01 & & $-1.30 \pm 0.78$ & Cinquemani et al. (1982) & 3 \\
\hline 27 & Sea Island City & -74.700 & 39.200 & QC-851 & $2345 \pm 100$ & $2714-2149$ & 0.01 & & $-2.80 \pm 0.79$ & Cinquemani et al. (1982) & 3 \\
\hline 28 & Sea Island City- NJ & -74.700 & 39.200 & QC-853 & $2760 \pm 100$ & $3204-2720$ & 0.04 & & $-4.72 \pm 0.77$ & Cinquemani et al. (1982) & 3 \\
\hline 29 & Sea Island City & -74.700 & 39.200 & QC-854 & $3440 \pm 110$ & $3980-3445$ & 0.01 & & $-5.50 \pm 0.80$ & Cinquemani et al. (1982) & 3 \\
\hline 30 & Sea Island City & -74.700 & 39.200 & QC-855 & $3960 \pm 110$ & 4815-4092 & 0.01 & & $-7.35 \pm 0.80$ & Cinquemani et al. (1982) & 3 \\
\hline 31 & Sea Island City & -74.730 & 39.180 & QC-852 & $2260 \pm 100$ & 2694-1993 & 0.02 & & $-3.49 \pm 0.78$ & Pardi et al. (1984) & 3 \\
\hline \multicolumn{12}{|c|}{ Index points (intercalated) } \\
\hline 34 & Brigantine Marsh & -74.354 & 39.420 & Unknown & $450 \pm 50$ & $616-319$ & 0.00 & 0.33 & $-0.49 \pm 0.67$ & Donnelly et al. (2004) & 3 \\
\hline 35 & Brigantine Marsh & -74.354 & 39.420 & Unknown & $1420 \pm 40$ & $1386-1284$ & -0.01 & 0.87 & $-1.74 \pm 0.68$ & Donnelly et al. (2004) & 3 \\
\hline 36 & Cheesequake Marsh & -74.300 & 40.400 & QC-845 & $4820 \pm 95$ & $5740-5319$ & -0.11 & 3.02 & $-8.04 \pm 0.94$ & Cinquemani et al. (1982) & 3 \\
\hline 37 & Great Bay & -74.320 & 39.510 & OS-34136 & $1200 \pm 35$ & $1257-1009$ & -0.02 & 0.68 & $-0.79 \pm 0.28$ & Miller et al. (2009) & 1 \\
\hline 38 & Great Bay & -74.320 & 39.510 & OS-34134 & $2890 \pm 30$ & $3156-2926$ & -0.04 & 1.71 & $-3.43 \pm 0.28$ & Miller et al. (2009) & 1 \\
\hline 39 & Great Bay & -74.342 & 39.549 & Unknown & $3050 \pm 95$ & $3448-2972$ & 0.00 & 2.04 & $-4.90 \pm 0.77$ & Psuty et al. (1986) & 3 \\
\hline 40 & Little Egg Inlet & -74.123 & 39.412 & GX-2966 & $7600 \pm 300$ & 9239-7799 & -0.52 & 2.06 & $-28.60 \pm 1.78$ & Field et al. (1979) & 1 \\
\hline 41 & Whale Beach & -74.671 & 39.184 & Beta-129433 & $60 \pm 40$ & 265-0 & 0.00 & 0.25 & $-0.32 \pm 0.79$ & Donnelly et al. (2001) & 2 \\
\hline 42 & Whale Beach & -74.671 & 39.184 & Beta-129432 & $110 \pm 40$ & $273-0$ & 0.00 & 0.29 & $-0.37 \pm 0.79$ & Donnelly et al. (2001) & 2 \\
\hline 43 & Whale Beach & -74.671 & 39.184 & Beta-129430 & $180 \pm 40$ & $301-0$ & 0.00 & 0.47 & $-0.85 \pm 0.79$ & Donnelly et al. (2001) & 2 \\
\hline 44 & Whale Beach & -74.671 & 39.184 & Beta-128149 & $210 \pm 40$ & $420-0$ & 0.00 & 0.25 & $-0.30 \pm 0.79$ & Donnelly et al. (2001) & 2 \\
\hline 45 & Whale Beach & -74.671 & 39.184 & Beta-131490 & $220 \pm 40$ & $425-0$ & 0.00 & 0.29 & $-0.37 \pm 0.79$ & Donnelly et al. (2001) & 2 \\
\hline 46 & Whale Beach & -74.671 & 39.184 & Beta-131489 & $230 \pm 40$ & $428-0$ & 0.00 & 0.36 & $-0.58 \pm 0.79$ & Donnelly et al. (2001) & 2 \\
\hline 47 & Whale Beach & -74.671 & 39.184 & Beta-124176 & $290 \pm 50$ & $490-0$ & 0.00 & 0.35 & $-0.54 \pm 0.79$ & Donnelly et al. (2001) & 2 \\
\hline 48 & Whale Beach & -74.671 & 39.184 & Beta-124177 & $300 \pm 40$ & $474-289$ & 0.00 & 0.32 & $-0.47 \pm 0.79$ & Donnelly et al. (2001) & 2 \\
\hline 49 & Whale Beach & -74.671 & 39.184 & Beta-123305 & $560 \pm 50$ & $652-513$ & 0.00 & 0.45 & $-0.82 \pm 0.79$ & Donnelly et al. (2001) & 2 \\
\hline 50 & Whale Beach & -74.671 & 39.184 & OS-26451 & $680 \pm 30$ & $680-561$ & 0.00 & 0.90 & $-1.95 \pm 0.79$ & Donnelly et al. (2001) & 2 \\
\hline \multicolumn{12}{|c|}{ Marine limiting } \\
\hline 1 & Cheesequake Marsh & -74.273 & 40.439 & Unknown & $4330 \pm 460$ & $5445-3124$ & & & $-10.29 \pm 0.58$ & Psuty et al. (1986) & 3 \\
\hline 2 & Rainbow Island I & -74.585 & 39.305 & GX-30879 & $2580 \pm 30$ & $2235-1921$ & & & $-4.54 \pm 0.14$ & Miller et al. (2009) & 4 \\
\hline 3 & Rainbow Island I & -74.585 & 39.305 & GX-30880 & $2880 \pm 30$ & $2645-2314$ & & & $-5.15 \pm 0.14$ & Miller et al. (2009) & 4 \\
\hline 4 & Rainbow Island II & -74.588 & 39.304 & GX-31527 & $2330 \pm 70$ & $1956-1561$ & & & $-3.60 \pm 0.14$ & Miller et al. (2009) & 4 \\
\hline 5 & Rainbow Island II & -74.588 & 39.304 & GX-31528 & $2980 \pm 40$ & $2719-2390$ & & & $-4.05 \pm 0.14$ & Miller et al. (2009) & 4 \\
\hline \multicolumn{12}{|c|}{ Terrestrial limiting } \\
\hline 1 & Cheesequake Marsh & -74.281 & 40.435 & Unknown & $6020 \pm 215$ & $7413-6403$ & & & $-7.59 \pm 0.58$ & Psuty et al. (1986) & 2 \\
\hline 2 & Cheesequake Marsh & -74.273 & 40.439 & Unknown & $6610 \pm 215$ & $7929-7020$ & & & $-10.99 \pm 0.58$ & Psuty et al. (1986) & 2 \\
\hline 3 & Cheesequake Marsh & -74.300 & 40.400 & QC-896 & $7320 \pm 185$ & $8508-7756$ & & & $-11.24 \pm 0.58$ & Cinquemani et al. (1982) & 3 \\
\hline 4 & Cheesequake Marsh & -74.273 & 40.439 & Unknown & $7735 \pm 195$ & $9086-8163$ & & & $-11.79 \pm 0.58$ & Psuty et al. (1986) & 3 \\
\hline 5 & Union Beach & -74.161 & 40.446 & Unknown & $660 \pm 110$ & $896-497$ & & & $-0.59 \pm 0.57$ & Psuty et al. (1986) & 3 \\
\hline
\end{tabular}

Relative sea level (RSL) is calculated by subtracting the reference water level from sample altitude, shown to two decimal places. A correction for tidal range change is applied to basal and intercalated index points. A correction for compaction is applied to intercalated index points. The RSL error range is calculated as the square root of the sum of squares of elevational error, sample thickness, tide-level error and indicative range, shown to two decimal places. The indicative range (given as a maximum) is the most probable vertical range in which the sample occurs, but for marine and terrestrial limiting dates the sample could occur below or above this range, respectively. Every index point for the New Jersey sealevel database has been age dated using radiocarbon techniques and calibrated using CALIB 6.1 (Reimer et al., 2009) with a $2 \sigma$ error, where zero is AD 1950. We include a code indicating the main line of evidence that led to the classification as an index point $(1,2,3)$, terrestrial limiting $(2,3)$ or marine limiting $(3,4)$ date $(1=$ microfossils, $2=$ plant macrofossils, $3=$ author listing, $4=$ identified estuarine/marine shells or foraminifera. 

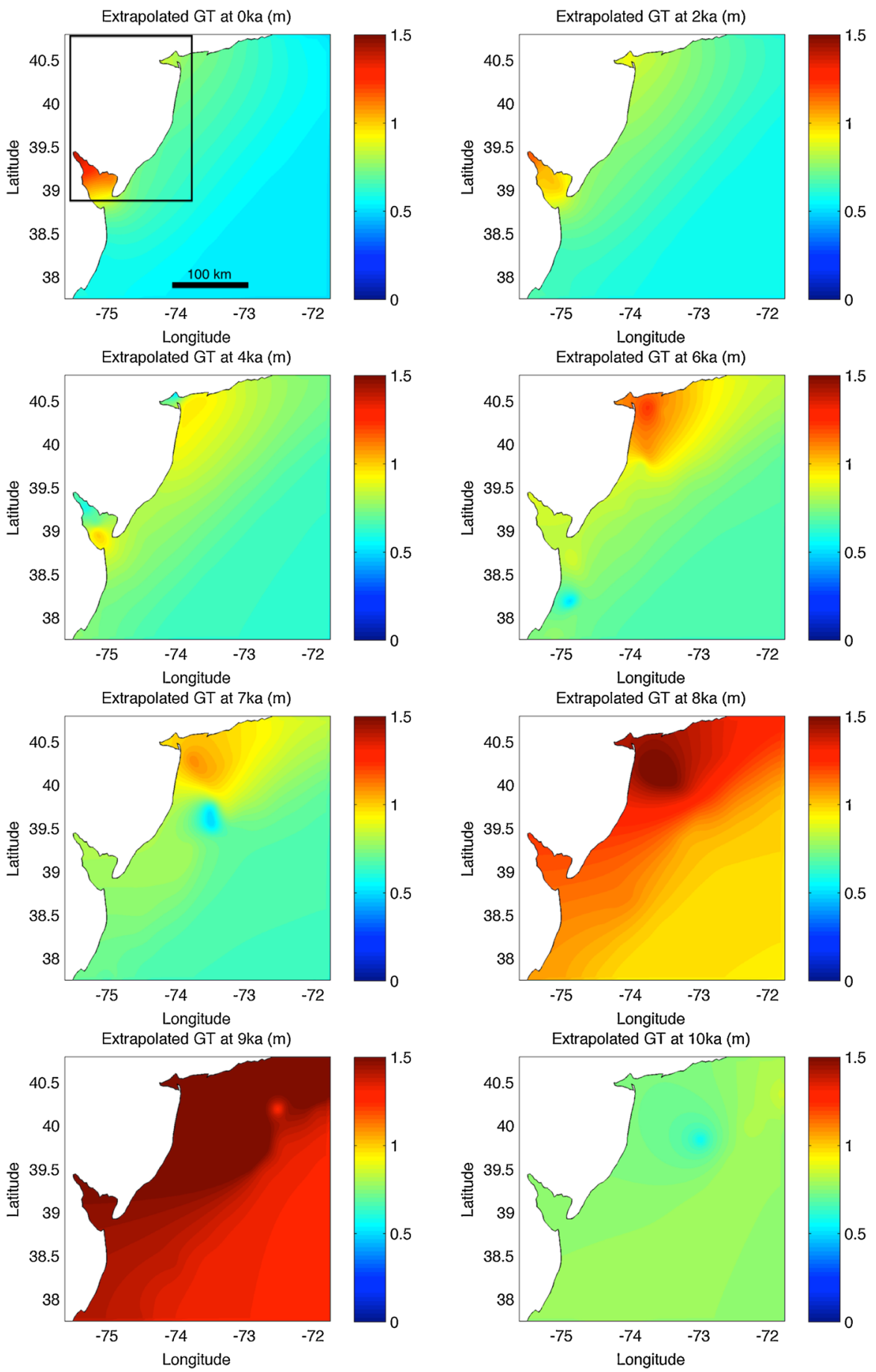

Figure 2. Contours of Great Diurnal Range (GT) at selected times during the Holocene. Panel showing GT at 0 ka shows the approximate area of Fig. 1 where the sea-level index points were generated.

residuals $(r=0.85)$. There is no relationship (at the $1 \%$ level) between the depth to basement (Fig. 4c) and total sediment thickness (Fig. 4d) and residuals.

While the intercalated index point dataset is of limited size, these results are consistent with previous studies from the UK (e.g. Shennan et al., 2000a; Edwards, 2006; Horton and Shennan, 2009) and the US Gulf coast (Törnqvist et al., 2008) and suggest that sediment compaction produces vertical scatter in RSL data. We used the linear regression between residuals and depth of overburden (with the outlying Little Egg Inlet index point excluded) to 'decompact' the intercalated index points (Edwards, 2006). This first-order decompaction procedure elevates the intercalated index points by as much as $3 \mathrm{~m}$ and moves them into much closer agreement with the basal index points and modeled curve. This procedure reduces the vertical scatter among index points.

\section{Holocene sea-level history}

The tidal range and sediment compaction-corrected sea-level index points from New Jersey show a continuous rise during the Holocene (Fig. 5). If we assume the Little Egg index point at $8.5 \mathrm{ka}$ no longer accurately estimates former RSL, the remaining index points suggest RSL was between -18 and $-22 \mathrm{~m}$ at $10-8 \mathrm{ka}$. RSL rose at an average of $4 \mathrm{~mm} \mathrm{a}^{-1}$ from $10 \mathrm{ka}$ to $6 \mathrm{ka}$ when RSL was between -8 and $-10 \mathrm{~m}$. RSL rise slowed to $2 \mathrm{~mm} \mathrm{a}^{-1}$ from 6 ka to 2 ka because of the diminishing response of the Earth's mantle to GIA and 

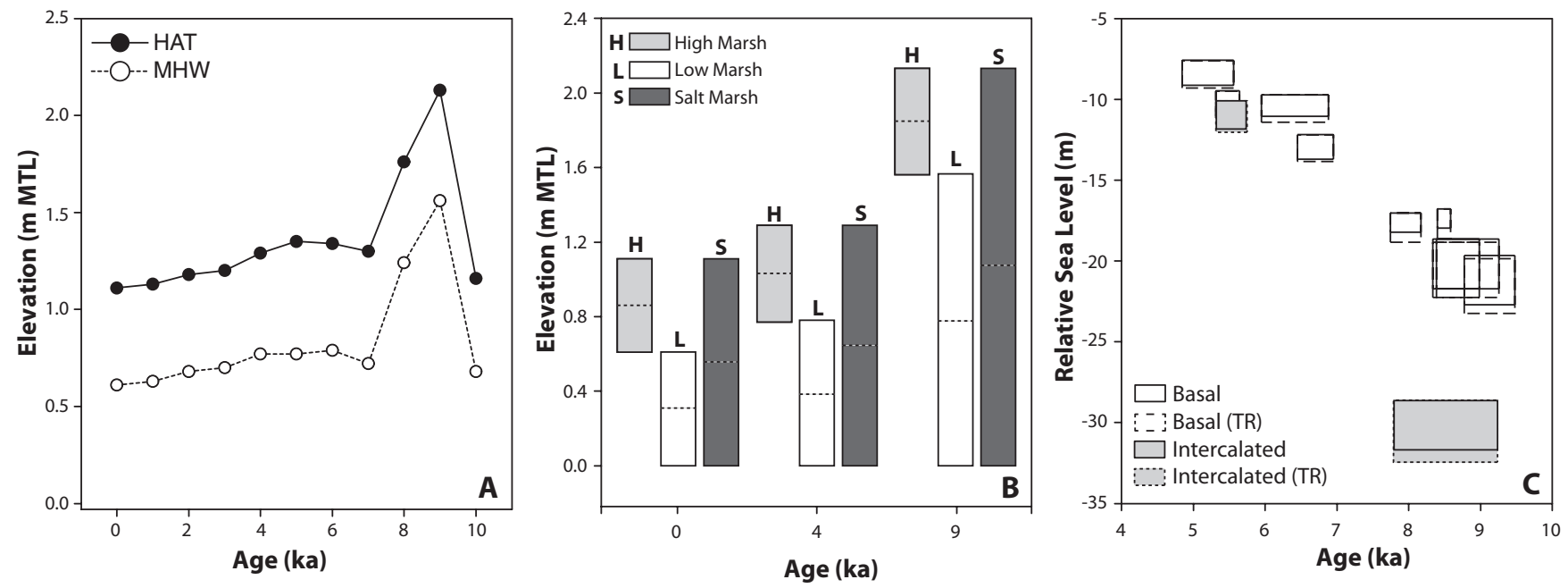

Figure 3. (A) Tidal data used to generate the indicative meanings (HAT, highest astronomical tide; MHW, mean high water; MTL, mean tide level) during the Holocene for Brigantine, NJ. (B) Reference water level and indicative range of saltmarsh, high marsh and low marsh at 0,4 and 9 ka for Brigantine, NJ. (C) Sea-level index points with and without tidal range change correction in the mid and early Holocene.
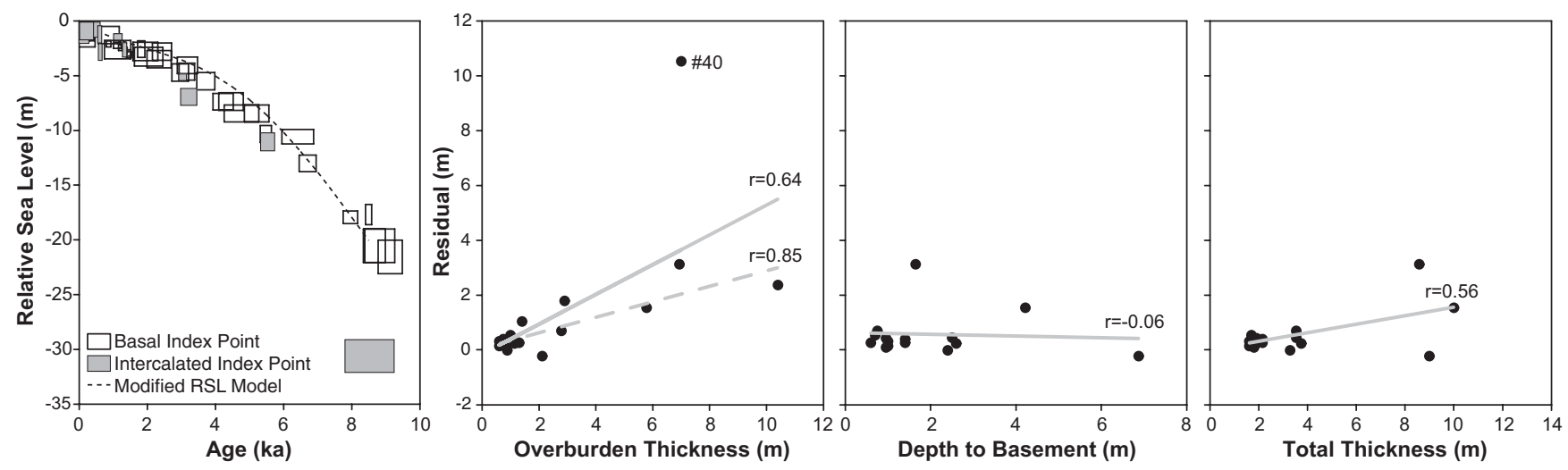

Figure 4. Sea-level index points and limiting data subdivided into basal and intercalated and the RSL curve. Overburden, depth to basement and total thickness of sediment versus residual for intercalated index points. 'Residual' is the difference between the fitted RSL curve and the center point of each intercalated index point.

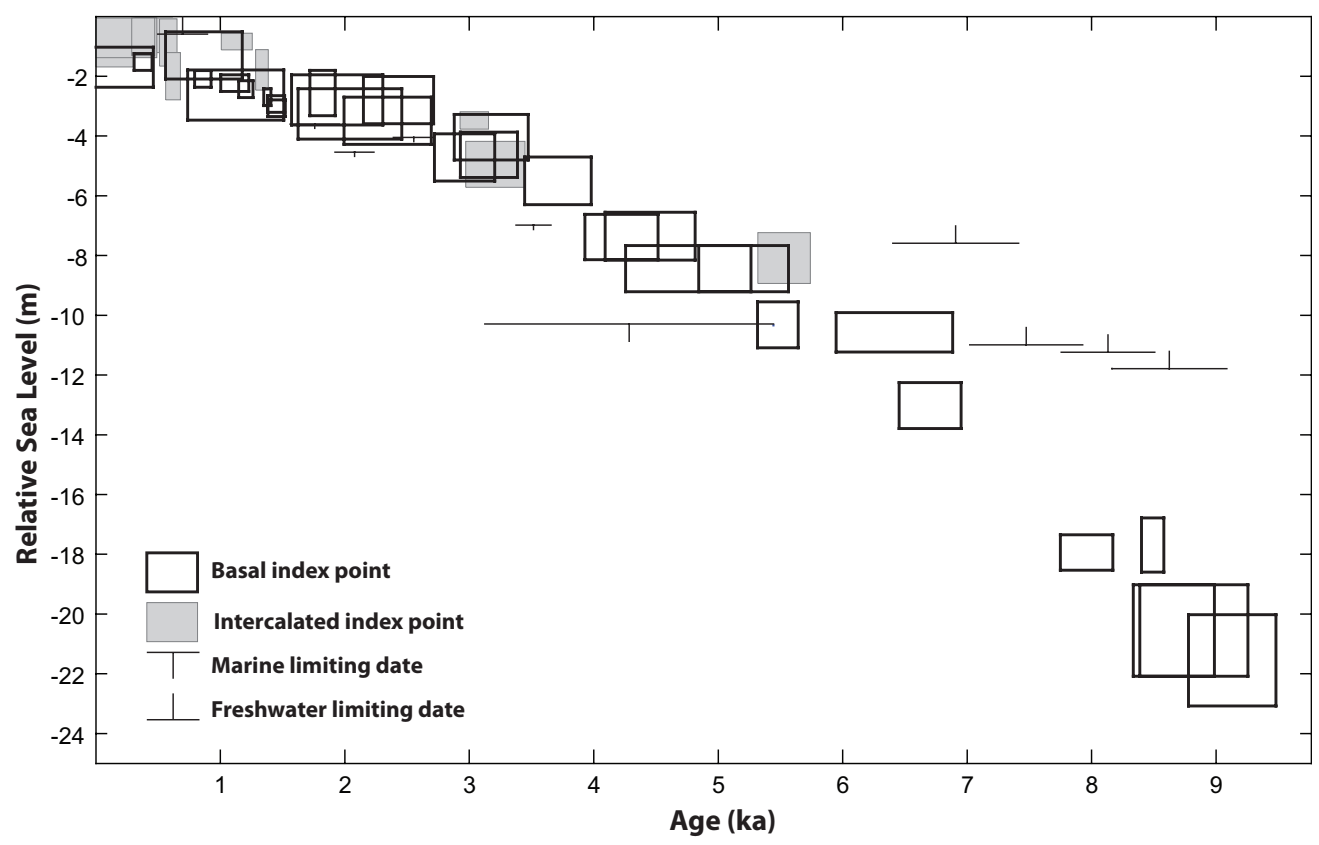

Figure 5. Holocene sea-level index points and limiting dates from New Jersey. Decompacted and tidal range corrected basal and intercalated index points are plotted as boxes with $2 \sigma$ vertical and calibrated age errors. 
reduction of eustatic input (Milne et al., 2005; Englehart and Horton, 2012). From 2 ka to AD 1900, we calculated a rate of $1.3 \pm 0.1 \mathrm{~mm} \mathrm{a}^{-1}$, which is almost all due to GIA (Peltier, 1998; Lambeck, 2002; Milne et al., 2005).

\section{Conclusions}

We updated a published Holocene sea-level database to generate 50 sea-level index points and ten limiting dates for New Jersey. Rates of RSL change were highest during the early and mid Holocene and decreased since. Reconstructions of RSL and modeled paleobathymetry for 1 ka time steps through the Holocene predict significant changes in tidal regimes as the transgression of the continental shelf progresses. The most significant changes occur in the upper Delaware Bay during the late Holocene, south of Long Island in the mid Holocene and the basin-wide amplification of the tide at 9-8 ka. However, these paleotidal changes have only minor implications in the analysis of Holocene RSL because of the microtidal regime. In contrast, sediment compaction explains meter-scale variations in elevation of RSL derived from index points taken from basal peat and those from peat intercalated within thick successions of Holocene sediments. We decompacted the intercalated index points using the thickness of sediment overburden, reducing the vertical scatter in sea-level reconstructions.

Acknowledgements. Funding for this study was provided by NICRR grant DE-FC02-06ER64298, National Science Foundation awards EAR 0717364, 1052848 and 0951686, NOAA grant NA11OAR4310101 and a Yale Climate and Energy Institute post-doctoral fellowship. This research was supported by the Earthwatch Institute Student Challenge Award Program and we thank the students who participated so enthusiastically in fieldwork. The Edwin Forsythe National Wildlife Refuge (US Fish and Wildlife Service) is acknowledged for their cooperation and for providing access to study sites. We acknowledge the researchers who collected the data, which has subsequently been reanalyzed in this study, and greatly appreciate their assistance and advice throughout this process. We thank Patrick Kiden and an anonymous reviewer, whose comments improved the manuscript. This paper is a contribution to IGCP project 588 'Preparing for coastal change' and PALSEA.

Abbreviations. GIA, glacial isostatic adjustment; GT, Great Diurnal Range; RSL, relative sea level

\section{References}

Allen JRL. 2000. Morphodynamics of Holocene salt marshes: a review sketch from the Atlantic and southern North Sea coasts of Europe. Quaternary Science Reviews 19: 1155-1231.

Bassett SE, Milne GA, Mitrovica JX, et al. 2005. Ice sheet and solid earth influences on far-field sea-level histories. Science 309: 925928.

Bloom AL. 1967. Pleistocene shorelines: a new test of isostasy. Geological Society of America Bulletin 78: 1477-1494.

Brain MJ, Long AJ, Petley DN, et al. 2011. Compression behavior of minerogenic low energy intertidal sediments. Sedimentary Geology 23: 28-41.

Brain MJ, Long AJ, Woodroffe SA, et al. 2012. Modelling the effects of sediment compaction on salt marsh reconstructions of recent sea-level rise. Earth and Planetary Science Letters 345-348: 180193.

Byrnes MR, Hammer RM, Thibaut TD, et al. 2004. Effects of sand mining on physical processes and biological communities offshore New Jersey, U.S.A. Journal of Coastal Research 20: 25-43.

Cahoon DR, Lynch JC, Hensel P, et al. 2002. A device for high precision measurement of wetland sediment elevation. I. Recent improvements to the sedimentation-erosion table. Journal of Sedimentary Research 72: 730-733.
Cinquemani LJ, Newman WS, Sperling JA, et al. 1982. Holocene sea level fluctuations, magnitudes and causes. IGCP Annual Meeting, Columbia, SC; $13-33$.

Daddario JJ. 1961. A lagoon deposit profile near Atlantic City, New Jersey. Bulletin of the New Jersey Academy of Science 6: 7-14.

Deschamps P, Durand N, Bard E, et al. 2012. Ice sheet collapse and sea-level rise at the Bølling warming, 14,600 yr ago. Nature 483: 559-564.

Donnelly JP, Roll S, Wengren M, et al. 2001. Sedimentary evidence of intense hurricane strikes from New Jersey. Geology 29: 615618.

Donnelly JP, Butler J, Roll S, et al. 2004. A backbarrier overwash record of intense storms from Brigantine, New Jersey. Marine Geology 210: 107-121.

Edwards RJ. 2006. Mid- to late-Holocene relative sea-level change in southwest Britain and the influence of sediment compaction. Holocene 16: 575-587.

Engelhart SE, Horton BP. 2012. Holocene sea level database for the Atlantic coast of the United States. Quaternary Science Reviews 54: 12-25.

Engelhart SE, Horton BP, Douglas BC, et al. 2009. Spatial variability of late Holocene and 20th century sea-level rise along the Atlantic coast of the United States. Geology 37: 1115-1118.

Engelhart SE, Peltier WR, Horton BP. 2011. Holocene relative sealevel changes and glacial isostatic adjustment of the U.S. Atlantic coast. Geology 39: 751-754.

Field ME, Meisburger EP, Stanley EA, et al. 1979. Upper Quaternary peat deposits on the Atlantic inner shelf of the United States. Geological Society of America Bulletin 90: 618-628.

Gehrels WR. 1999. Middle and late Holocene sea-level changes in Eastern Maine reconstructed from foraminiferal saltmarsh stratigraphy and AMS C-14 dates on basal peat. Quaternary Research 52: 350-359.

Gehrels WR, Belknap D, Pearce B, et al. 1995. Modeling the contribution of M2 tidal amplification to the Holocene rise of mean high water in the Gulf of Maine and Bay of Fundy. Marine Geology 124: 71-85.

Griffiths SD, Peltier WR. 2008. Megatides in the Arctic Ocean under glacial conditions. Geophysical Research Letters 35: L08605.

Griffiths SD, Peltier WR. 2009. Modeling of polar ocean tides at the Last Glacial Maximum: amplification, sensitivity, and climatological implications. Journal of Climate 22: 2905-2924.

Hall GF, Hill DF, Horton BP, et al. 2013. A high-resolution study of tides in the Delaware Bay: past conditions and future scenarios. Geophysical Research Letters 40: 338-342.

Hill DF, Griffiths SD, Peltier WR, et al. 2011. High resolution numerical modeling of tides in the western Atlantic, Gulf of Mexico, and Caribbean Sea during the Holocene. Journal of Geophysical Research 116: C10014.

Hinton A. 1992. Paleotidal changes within the area of the Wash during the Holocene. Proceedings of the Geology Association 103: 259-272.

Horton BP, Shennan I. 2009. Compaction of Holocene strata and the implications for relative sea-level change on the east coast of England. Geology 37: 1083-1086.

Jelgersma S. 1961. Holocene sea-level changes in the Netherlands. Mededelingen Geologische Stichting Serie C VI: 1-100.

Kaye CA, Barghoorn ES. 1964. Late Quaternary sea-level change and crustal rise at Boston, Massachusetts, with notes on the autocompaction of peat. Geological Society of America Bulletin 75: 63-80.

Kemp AC, Vane CH, Horton BP, et al. 2012a. Application of stable carbon isotopes for reconstructing salt-marsh floral zones and relative sea level, New Jersey, USA. Journal of Quaternary Science 27: 404-414.

Kemp AC, Horton BP, Vann DR, et al. 2012b. Quantitative vertical zonation of salt-marsh foraminifera for reconstructing former sea level: an example from New Jersey, USA. Quaternary Science Reviews 54: 26-39.

Lambeck K. 2002. Sea level change from mid-Holocene to recent time: an Australian example with global implications. In Ice Sheets, Sea Level and the Dynamic Earth, Mitrovica JX, Vermeersen BLA (eds.). AGU: Washington, DC; 33-50. 
Lambeck K, Chappell J. 2001. Sea level change through the last glacial cycle. Science 292: 679-685.

Long AJ, Waller MP, Stupples P. 2006. Driving mechanisms of coastal change: peat compaction and the destruction of late Holocene coastal wetlands. Marine Geology 225: 63-84.

Luettich R, Westerink J. 1991. A solution for the vertical variation of stress, rather than velocity, in a three-dimensional circulation model. International Journal for Numerical Methods in Fluids 12: 911-928.

Meyerson AL. 1972. Pollen and paleosalinity analysis from a Holocene tidal marsh sequence, Cape May County, New Jersey. Marine Geology 12: 335-357.

Miller KG, Sugarman PJ, Browning JV, et al. 2009. Sea-level rise in New Jersey over the past 5000 years: implications to anthropogenic changes. Global and Planetary Change 66: 10-18.

Milne GA, Long AJ, Bassett SE. 2005. Modelling Holocene relative sea-level observations from the Caribbean and South America. Quaternary Science Reviews 24: 1183-1202.

Mitrovica JX, Milne GA. 2002. On the origin of late Holocene sealevel highstands within equatorial ocean basins. Quaternary Science Reviews 21: 2179-2190.

Mofjeld H, Venturato A, Gonzales F, et al. 2004. The harmonic constant datum method: options for overcoming datum discontinuities at mixed-diurnal tidal transitions. Journal of Atmospheric and Oceanic Technology 21: 95-104.

NOAA. 2000. Special Publication NOS CO-OPS 1: Tidal Datums and their Applications. NOAA: Silver Spring, MD.

Pardi RR, Tomecek L, Newman WS. 1984. Queens college radiocarbon measurements IV. Radiocarbon 26: 412-430.

Parker BB. 1991. The relative importance of the various nonlinear mechanisms in a wide range of tidal interactions. In Tidal Hydrodynamics, Parker BB (ed.). Wiley: New York; 237268.

Peltier WR. 1998. Postglacial variations in the level of the sea: implications for climate dynamics and solid-earth geophysics. Reviews of Geophysics 36: 603-689.
Peltier WR. 2004. Global glacial isostasy and the surface of the iceage Earth: the ICE-5G(VM2) model and GRACE. Annual Review of Earth and Planetary Science 32: 111-149.

Psuty NP. 1986. Holocene sea level in New Jersey. Physical Geography 7: 156-167.

Reimer PJ, Baillie MGL, Bard E, et al. 2009. IntCal09 and Marine09 radiocarbon age calibration curves, 0-50,000 years cal BP. Radiocarbon 51: 1111-1150.

Shennan I, Horton BP. 2002. Holocene land- and sea-level changes in Great Britain. Journal of Quaternary Science 17: 511-526.

Shennan I, Lambeck K, Horton BP, et al. 2000a. Holocene isostasy and relative sea-level changes on the east coast of England Special Publication 166. Geological Society: London; 275-298.

Shennan I, Lambeck K, Flather R, et al. 2000b. Modelling western North Sea palaeogeographies and tidal changes during the Holocene. Special Publication 166. Geological Society: London; 299319.

Stahl L, Koczan J, Swift D. 1974. Anatomy of a shoreface-connected sand ridge on the New Jersey shelf: implications for the genesis of the shelf surficial sand sheet. Geology 2: 117-120.

Stuiver M, Daddario JJ. 1963. Submergence of the New Jersey Coast. Science 142: 951.

Sykes LR, Armbruster JG, Kim WY, et al. 2008. Observations and tectonic setting of historic and instrumentally located earthquakes in the greater New York City-Philadelphia Area. Bulletin of the Seismological Society of America 98: 1696-1719.

Törnqvist TE, Wallace DJ, Storms JEA, et al. 2008. Mississippi Delta subsidence primarily caused by compaction of Holocene strata. Nature Geoscience 1: 173-176.

Tushingham AM, Peltier WR. 1992. Validation of the ICE-3G model of Wurm-Wisconsin deglaciation using a global data-base of relative sea-level histories. Journal of Geophysical Research: Solid Earth 97: 3285-3304.

Uehara K, Scourse JD, Horsburgh JK, et al. 2006. Tidal evolution of the northwest European shelf seas from the Last Glacial Maximum to the present. Journal of Geophysical Research 111: no. C9. 